\title{
Assessment of Hydraulic Conductivity of Some Nigerian Hardwood Timbers to Four Timber Treatment Chemicals through Quantitative Anatomical Studies
}

\author{
G. C. Ajuziogu' ${ }^{1}$, R. C. Njokuocha ${ }^{1}$, N. M. Eze ${ }^{1}$, I. E. Ngele ${ }^{1}$, G. N. Ogbuagu ${ }^{1}$ \\ and E. O. Ojua ${ }^{1^{*}}$ \\ ${ }^{1}$ Department of Plant Science and Biotechnology, University of Nigeria, Nsukka, Nigeria.
}

\begin{abstract}
Authors' contributions
This work was carried out in collaboration among all authors. Authors GCA and RCN designed the study, supervised the study, managed the analyses of the study and wrote the first draft of the manuscript. Authors IEN, NME and GNO conducted the research, collected the data and managed the literature searches. Author EOO conducted the research, collected the data, managed the literature searches, performed the statistical analysis and edited the first draft of the manuscript. All authors read and approved the final manuscript.

Article Information

DOI: $10.9734 / A R R B / 2020 / v 35 i 630235$

Editor(s):

(1) Paola Angelini, University of Perugia, Italy.

Reviewers:

(1) Diego Ribeiro de Aguiar, Universidade Federal do Oeste do Pará, Brazil.

(2) Matheus Bortolanza Soares, Brazil. (3) Dimaghi Schwamback, University of São Paulo, Brazil. Complete Peer review History: http://www.sdiarticle4.com/review-history/57817
\end{abstract}

Original Research Article

Received 17 April 2020

Accepted 23 June 2020

Published 06 July 2020

\begin{abstract}
Aim: Hydraulic conductivity following the Hagen-Poiseuille Law is a quantitative approach to determine the treatability of wood by chemicals. The hydraulic conductivities of the ten selected Nigerian hardwood timber species to four wood treatment chemicals were estimated, using HagenPeiseuille equation.

Materials and Methods: Ten timber species of marketable size and age were sourced from the forestry Departments of Enugu, Anambra and Abia States of Nigeria. Maceration were carried out following standard procedures. The viscosities in centipoises (cp) of the four wood treatment chemicals were measured in a viscometer test, while the hydraulic conductivities were calculated using the Hagen-Peiseuille equation.
\end{abstract}


Results: The results obtained show that the different woods responded differently to the chemicals. Treatment with Folithion 200 showed higher conductivity in Triplochiton scleroxylon $\left(9.01 \mathrm{~mm}^{-3} \mathrm{~S}^{-1} \times\right.$ $10^{-5}$ ), followed by Mansonia altissima, Milicia excelsa and Terminalia superb. The order of conductivity to treatment with Actellic 25EO was Terminalia superba > Mansonia altissima > Gmelina arborea, > Khaya ivorensis. Ceiba pentandra gave the highest conductivity of $8.58 \mathrm{~mm}^{-3} \mathrm{~S}^{-}$ ${ }^{1} \times 10^{-5}$, followed by Afzelia africana and Canarium schwenfurthii to the chemical Termitox. While Triplochiton scleroxylon gave the highest conductivity of $6.52 \mathrm{~mm}^{-3} \mathrm{~S}^{-1} \times 10^{-5}$, followed by Milicia excels and Terminalia superba to the chemical Solignum.

Conclusion: Folithion 200 would be effective on Milicia excels, Mansonia altissima and Gmelina arborea, Actellic 25 EO would be effective on Khaya ivorensis, Terminalia superb and Antiaris toxicaria while Termitox would be effective on Ceiba pentandra, Afzelia Africana and Canarium schweinfurthii.

Keywords: Hagen-poiseuille law; wood vessels; treatability.

\section{INTRODUCTION}

Timber is wood specially prepared for building, carpentry and many other uses. It is strong, absorbs shocks, is not affected by normal variations in temperature and is a good insulator [1]. It has been estimated that of the roughly 374,000 species of plant in the world, 308,312 are vascular plants of which $45-48 \%$ are woody, and of these, only a few are used for timber purposes $[2,3]$. As the demand for timber is rapidly increasing, new species are considered as alternatives for the fast depleting known commercial timbers [4]. Timber is obtained almost exclusively from coniferous and dicotyledonous trees. Conifers have more uniform structures with fewer wood elements. In contrast, the dicotyledons have coarse structure with many wood elements. Wood from conifers is commercially known as softwood, while those of the dicotyledons are called hardwood, though these terms do not translate to physical strength [5].

Wood scientifically is the secondary xylem of gymnosperms and woody dicots. It is derived from the activities of the vascular cambium, which is one of the lateral meristerms in trees that undergo secondary growth. It effects the translocation of water and dissolved minerals from the root to stems and leaves [6-8]. Wood is a biological material, and is prone to degradation by both micro and macro- organisms. The primary metabolites: Soluble sugars, lipids and peptides, together with the major storage compound starch provide the main supply of readily assimilable carbon sources for fungi and other organisms growing on wood. However, with seasonally sugary sap (e.g. Acer sp.), these substances occur in relatively small amounts, and are found almost exclusively in living or recently dead sapwood parenchyma. They enable development of certain micro fungi such as those causing blue stain in conifers, which cannot degrade cell wall components, and may also facilitate establishment of decay fungi, but are rapidly depleted during fungal colonization $[9,10]$. The amount of primary metabolites vary according to seasonal and other factors, but may be as high as $7 \%$ for starch and $2.5 \%$ for lipids, with the amount of starch sometimes being maximal in the middle sapwood and declining to zero at the heartwood boundary $[10,11]$.

Structural cell wall components form the dominant available carbon sources for fungi growing in wood, but in being relatively refractive impose a degree of nutritional stress. The major types are cellulose, the Hemicelluloses and lignin, each of which can be utilized to different extents by different fungi and whose relative proportions can vary considerably in wood both from the same and different trees $[9,12]$. Cellulose is usually the dominant constituent, accounting for $40-50 \%$ of dry weight of extractive free materials in undecayed wood of both angiosperm and gymnosperm trees. It also occurs in higher proportions in tension wood than in normal wood [7]. Cellulose is based on a straight-chain molecule arising from $\beta$ 1:4 linkage of glucose units. The chains are in turn organized into a crystalline or miceller substructure within the microfibrils. Their fibrilar structure is of particular importance in providing tensile strength in wood, and cellulose has in consequence sometimes been classified as a framework substance. When bound together with matrix substances- the hemicelluloses and lignin, this makes for a mechanically strong material. This material is the major constituent of the secondary xylem-wood [6]. Hemicelluloses, which are of relatively low molecular weight, are branched-or- 
straight-chain polymers of hexose, pentose or uronic acid subunits. They tend to occur at somewhat higher levels (25-40\%) in temperate angiospermous woods than in coniferous woods $(25-30 \%) \quad[13,14]$. Lignins are aromatic substances resulting from the polymerization of phenyl propanoid subunits to for a very complex type of molecules [13]. They are usually present in larger amounts $(25-30 \%)$ in coniferous woods than in temperate angiosermous woods (18$25 \%$ ), but may occur in substantial quantity in certain tropical angiosperms $[15,16]$.

Besides structural cell wall components, primary metabolites and storage compounds, wood contains a wide range of extraneous materials known as extractives, which can be removed using either neutral organic solvents or water [9]. The presences of some extractives in wood play a major role in the natural wood durability [17]. Wood as a material is made up of various wood elements (cells), of which most of them are axial in orientation, these include various fibres, vessels and various parenchyma cells. These elements have lumens, which gives the wood its porous nature [8]. Treatment of timber with preservative chemicals takes the advantage of this porous nature wood. The treatability of any wood species largely depends on the nature of the various wood elements present in that species and on the nature of the preservative chemical involved [18]. In the present work, an attempt has been made to the hydraulic conductivities of vessels in ten Nigerian hardwood timber species to four chemical wood preservatives using the Hagen-Peiseuille equation.

\section{MATERIALS AND METHODS}

Ten timber species of (Table 1) marketable size and age were sourced from the forestry Departments of Enugu, Anambra and Abia States of Nigeria. The species are wildly distributed in the natural rain forest zones of Nigeria and elsewhere in West Africa, where the annual rainfall is about $1500 \mathrm{~mm}$ and above.

The ten species were selected due to their high frequency in usage in the Eastern Nigeria. Milicia excels, Khaya ivorensis, Gmelina arborea and Triplochiton scleroxylon are highly sought after in building construction; Mansonia altissima and Afzelia africana in furniture-making; Terminalia superba and Canarium schwenfurthii as cores in plywood making and in flush-doors, while Ceiba pentandra and Antiaris toxicaria are used in making formers for concrete casting during structural construction works.

Small portion of each of the species $(3 \mathrm{~cm} \times 6$ $\mathrm{cm}$ ), were cut off and oven-dried for several hours at $80^{\circ} \mathrm{C}$ and weighed at intervals until no net change in weight was recorded. This was done to reduce the moisture content of the species to the barest minimum in readiness for wood maceration process. The Schultz's method of wood maceration as adopted by Ajuziogu et al. [19] was used. This method included chopping of the wood into small sizes of about the size of a match-stick into a test tube, and adding $\mathrm{KClO}_{3}$ crystals and Conc. $\mathrm{HNO}_{3}$ into the test-tubes and allowed to react in a fume cupboard, until all the chips were softened and bleached.

After the reactions, excess solutions were decanted off from each test-tube, and the soft bleached chip (then in form of pulp) were washed several times in distilled water to prevent further reactions. The pulps were transferred separately into well-labeled specimen bottles - two bottles ( $A$ and $B$ ) for each specimen, bringing the total number of specimen bottles to twenty. Two drops of phenol and glycerin were added into each of the bottles respectively. The phenol prevents molding, while glycerin removes air bubbles in the bottles. The pulps were shaken with glass beads to help tease out the wood elements in separate units for ease of measurements. The contents of the bottles were stained with brilliant crystal blue and safranine for groups $A$ and $B$ respectively. Stained vessel members were isolated and mounted on a slide in $30 \%$ glycerin, and carefully covered with cover slip. Examinations and measurements were made under a calibrated light microscope at 100x magnification. The microscope used was a KYOWA TOKYO JAPAN monocular microscope to which a calibrated ocular micrometer was fitted in the ocular-tube.

The measurement taken were Vessel member length (I) and Vessel lumen diameter (d) while the vessel member radius ( $r$ ) was calculated by dividing each lumen diameter by $2: r=d / 2$. Thirty measurements were made for each of vessel parameter per wood species and the means and standard error noted.

The viscosities in centipoises (cp) of the four wood treatment chemicals, namely Solignum; Termitox; Actellic 25EO and Folithion 200 were measured in a viscometer test, using Ferranti Bitable Viscometer Model VL at $29^{\circ} \mathrm{C}$. 
Table 1. The timber species, families and their common names

\begin{tabular}{llll}
\hline Serial number & Timber species & Families & Common names \\
\hline 1. & Milicia excelsa (Welw.) Cl Berg. & Moraceae & Iroko \\
2. & Khaya ivorensis A. Chev. & Meliaceae & African mahogany \\
3. & Mansonia altissima A. Chev. & Sterculiaceae & African walnut \\
4. & Gmelina arborea Roxb. & Verbenaceae & Melina \\
5. & Terminalia superba Engl. \& Diels. & Combretaceae & Afara \\
6. & Ceiba pentandra (Linn.) Gaerth. & Bombacaceae & Silk cotton tree \\
7. & Triplochiton scleroxylon K. Schum. & Sterculiaceae & Obeche \\
8. & Antiaris toxicaria var. africana & Moraceae & Bark cloth tree \\
9. & Afzelia africana Sm. & Fabaceae- & Apa \\
10. & & Caesalpinoidae & Bush candle tree \\
\hline
\end{tabular}

The hydraulic conductivity $(K)$ of the vessels members of the ten species were calculated using the Hagen-Poiseuille equation: $Q=\pi r^{4} / 81 \eta$,

Where $Q=$ Hydraulic conductivity; $r=$ Vessel lumen radius; $I$ = vessel member Length; $D=$ Viscosity [20].

Data collected were subject to analysis of variance (ANOVA) while significant means were separated using Duncan Post Hoc Test using Statistical Package for Social Sciences software (IBM SPSS, Ver 20).

\section{RESULTS AND DISCUSSION}

A key factor used in determining hydraulic conductivity in wood vessels is the vessel lumen radius $(r)$ [21]. This is a factor inherent in trees, and this could be inferred from Table 2. The dimensional characteristics of the vessel members in the ten timber species are presented in Table 2. It was observed that the vessel lumen radius ranged from 0.05 to $0.126 \mathrm{~mm}$ across the ten species evaluated with Ceiba pentandra recording the widest radius. Therefore, it is expected that Ceiba pentandra would give greater conductivities.
Another factor that plays an important role in hydraulic conductivity is the viscosity of the fluid being conducted. Low viscous fluids tend to penetrate or move through pipes quite easier than fluids with high viscosity [22]. As observed on Table 3 , the viscosities of the fluids ranged from 2.06 in Termitox to 11.95 in Solignum and fluids with lower viscosities (Termitox) would be expected to have the highest conductivity. However, this was not the case as results in Fig. 1 showed that Folithion 200 recorded higher conductivity across most of the plant species. There were variations in the response of the different plants species with different chemicals with Triplochiton scleroxylon showing higher conductivity $\left(9.0167 \mathrm{~mm}^{-3} \mathrm{~S}^{-1} \times 10^{-5}\right)$ with Folithion 200 (Fig. 1). More so, Milicia excels, Mansonia altissima and Gmelina arborea showed significantly $(P<0.05)$ higher conductivity with Folithion 200 than the other chemicals. Khaya ivorensis, Terminalia superb and Antiaris toxicaria showed significantly $(P<0.05)$ higher conductivity with Actellic 25 EO, Ceiba pentandra, Afzelia Africana and Canarium schweinfurthii with Termitox while Solignum had lower conductivity across the plants.

Table 2. Dimensional characteristics of vessel members of the species in millimeters $(\mathrm{mm})$

\begin{tabular}{llll}
\hline Species & $\begin{array}{l}\text { Mean vessel } \\
\text { member length (I) }\end{array}$ & $\begin{array}{l}\text { Mean vessel member } \\
\text { diameter (d) }\end{array}$ & $\begin{array}{l}\text { Mean vessel lumen } \\
\text { Radius (r) }\end{array}$ \\
\hline Milicia excelsa & $0.405 \pm 0.091^{\mathrm{c}}$ & $0.198 \pm 0.038^{\mathrm{bc}}$ & $0.091 \pm 0.020^{\mathrm{bc}}$ \\
Khaya ivorensis & $0.432 \pm 0.107^{\mathrm{bc}}$ & $0.160 \pm 0.057^{\mathrm{c}}$ & $0.076 \pm 0.017^{\mathrm{cd}}$ \\
Mansonia altissima & $0.380 \pm 0.046^{\mathrm{c}}$ & $0.087 \pm 0.027^{\mathrm{d}}$ & $0.050 \pm 0.008^{\mathrm{f}}$ \\
Gmelina arborea & $0.286 \pm 0.085^{\mathrm{d}}$ & $0.156 \pm 0.048$ & $0.072 \pm 0.013^{\mathrm{de}}$ \\
Terminalia superba & $0.489 \pm 0.125^{\mathrm{ab}}$ & $0.204 \pm 0.055^{\mathrm{ab}}$ & $0.088 \pm 0.022^{\mathrm{bc}}$ \\
Ceiba pentandra & $0.560 \pm 0.100^{\mathrm{a}}$ & $0.232 \pm 0.053^{\mathrm{a}}$ & $0.126 \pm 0.020^{\mathrm{a}}$ \\
Triplochiton scleroxylon & $0.186 \pm 0.039^{\mathrm{e}}$ & $0.152 \pm 0.030^{\mathrm{c}}$ & $0.078 \pm 0.010^{\mathrm{cd}}$ \\
Antiaris toxicaria & $0.236 \pm 0.033^{\mathrm{de}}$ & $0.181 \pm 0.026^{\mathrm{bc}}$ & $0.060 \pm 0.011^{\mathrm{ef}}$ \\
Afzelia Africana & $0.233 \pm 0.062^{\mathrm{de}}$ & $0.195 \pm 0.035^{\mathrm{bc}}$ & $0.098 \pm 0.021^{\mathrm{b}}$ \\
Canarium schweinfurthii & $0.205 \pm 0.046^{\mathrm{de}}$ & $0.174 \pm 0.037^{\mathrm{bc}}$ & $0.091 \pm 0.015^{\mathrm{bc}}$ \\
\hline \multicolumn{2}{c}{${ }^{*}$ means with different alphabet along each vertical array represents significant differences at $P<0.05$}
\end{tabular}


Table 3. Viscosities of the chemicals at $29^{\circ} \mathrm{C}$ in Centipoises

\begin{tabular}{ll}
\hline Treatment chemicals & Viscosities \\
\hline Solignum & $11.95 \pm 0.15^{\mathrm{a}}$ \\
Termitox & $2.06 \pm 0.006^{\mathrm{d}}$ \\
Actellic 25 EO & $6.59 \pm 0.04^{\mathrm{c}}$ \\
Folithion 200 & $8.65 \pm 0.07^{\mathrm{b}}$ \\
\hline & ${ }^{*}$ means with different alphabet represents significant differences at $P<0.05$
\end{tabular}

In the present study, the expectations of wood with larger vessel lumen radius should give grater conductivity to the treatment fluids with lower viscosity was only met in Termitox with the lowest viscosity of $2.06 \pm 0.007$ with Ceiba pentandra, Afzelia Africana and Canarium schweinfurthii. However, the conductivities recorded were not the highest.

Alternatively there were non-conformities with this trend as Triplochiton scleroxylon having an average radius value of $0.078 \pm 0.010 \mathrm{~mm}$, had the highest conductivity with Folithion 200 which also had higher viscosity. All these nonconformities with the expected results cannot be explained by the vessel lumen radius and viscosity values alone. There could be other factor responsible for them.

Tyree and Ewers [23] affirmed that the hydraulic architecture in trees (wood) may have some salient influence in their water relations (conductivity). This could come in the manner in which the inner secondary walls of the vessel
Lumina were laid down during secondary wall formation. Evert [6] recognized four patterns to which the secondary wall or the wall next to the vessel lumen of could be laid. These include annular, helical, scalariform and reticulate. They show great diversity in their architecture, and as such could give diverse resistances to fluid conductivity. The affinities of the various treatment fluids to the lumina walls could equally be a factor contributing to conductivity, as capillary pressure varies greatly in different wood species [24]. According to Sperry et al. [25] endwalls contribute $56-64 \%$ to total xylem resistance in vessel and tracheids, indicating that length limits conducting efficiency. The cohesion forces between fluid molecules and their adhesion to the vessel lumen wall is of great importance [26]. Therefore, these factors (hydraulic architecture, affinities of the various treatment fluids to the lumina walls, end-walls) and some others may in one way or the other influence the nonconformities of the various wood species to their expected hydraulic conductivity to the various treatment fluids.

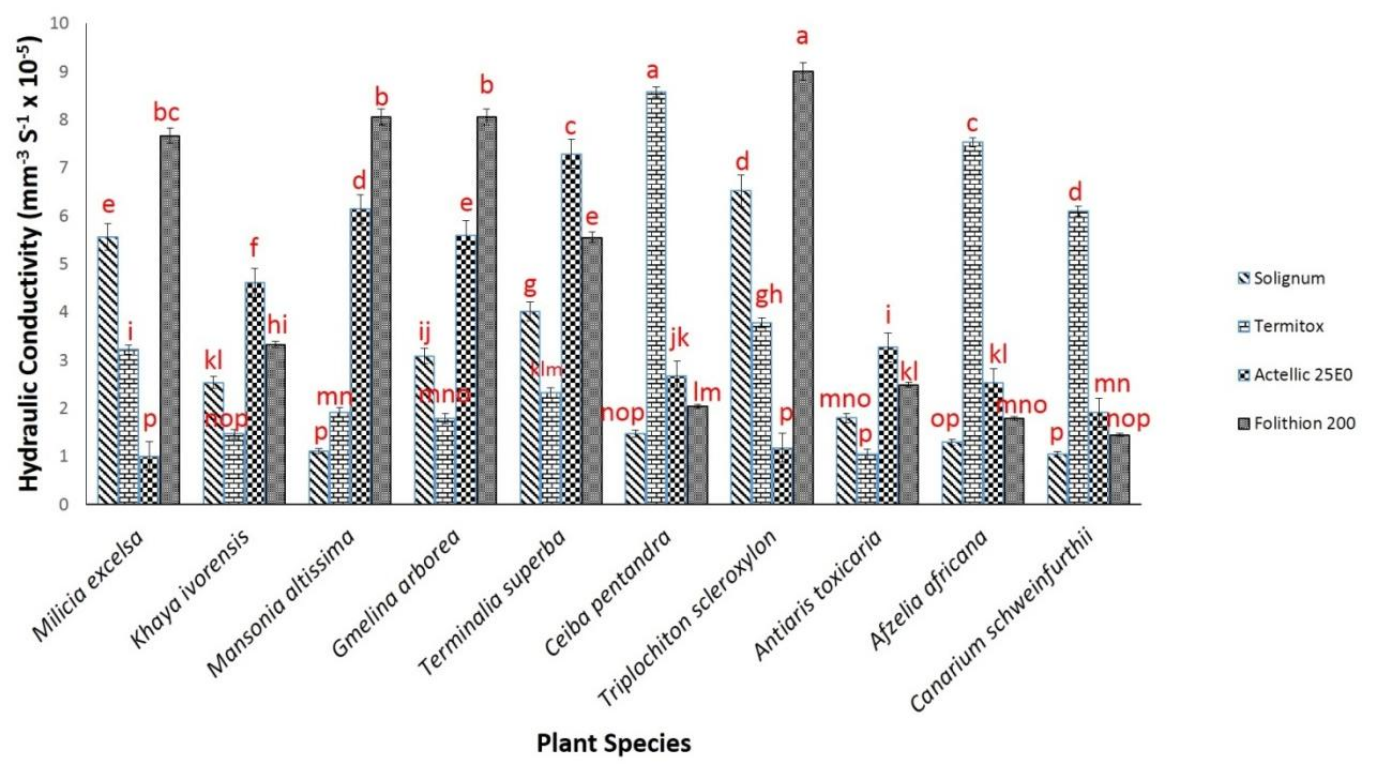

Fig. 1. The hydraulic conductivity of vessel to the treatment chemicals (bars with different alphabets are significantly different at $P<0.05$ ) 


\section{CONCLUSION}

According to Ajuziogu et al. [27] the hydraulic conductivity following the Hagen-Poiseuille Law is a quantitative approach to determine the treatability of wood by chemicals. Following this provision, it could be concluded that, folithion 200 would be effective on Milicia excels, Mansonia altissima and Gmelina arborea, Actellic 25 EO would be effective on Khaya ivorensis, Terminalia superb and Antiaris toxicaria while Termitox would be effective on Ceiba pentandra, Afzelia africana and Canarium schweinfurthii.

This study could be improved if the vessels measurements could be done with electron microscope to ensure higher precision. More so, since this study was based on quantitative analysis, the penetratability of preservatives on the different wood species using pressure treatment methods should be evaluated and compare.

\section{COMPETING INTERESTS}

Authors have declared that no competing interests exist.

\section{REFERENCES}

1. Ramage $M H$, Burridge $H$, Busse-Wicher $M$, Fereday G, Reynolds T, Shah DU, Wu G, $\mathrm{Yu} L$, Fleming $\mathrm{P}$, Densley-Tingley $\mathrm{D}$, Allwood J, Dupree $P$, Linden PF, Scherman $O$. The wood from the trees: The use of timber in construction. Renewable and Sustainable Energy Reviews. 2017;68(1):333-359.

2. FitzJohn RG, Pennell MW, Zanne $A E$, Stevens PF, Tank DC, Cornwell WK. How much of the world is woody? Journal of Ecology. 2014;102:1266-1272.

3. Maarten JM, Christen H, Byng JW. The number of known plants species in the world and its annual increase. Phytotaxa. 2016;261(3):201-217.

4. Hunter D. Paper-making: The history and technique of an ancient craft. Dover Publication, Inc.: Mineola, NY; 1978.

5. Green H. Wood: Craft, culture and history. Penguin Books: London, UK; 2007.

6. Evert RF. Esau's plant anatomy. $3^{\text {rd }}$ Edition. John Wiley and Sons, Inc.: Hoboken, NJ; 2006.

7. Cutler DF, Botha T, Stevenson WD. Plant Anatomy: An applied approach. Blackwell Publishing: Malden; 2007.
8. Oladele FA. Essential and applications of wood anatomy. J. Olu Olatiregun (Nig) Company Ltd: Ilorin, Nig; 1991.

9. Rayner ADM, Boddy L. Fungal decomposition of wood: Its biology and ecology. John Wiley and Sons: Chichester, UK; 1988.

10. Hugh $M$, Ari $M H$, Jansen S, Ribera J, Rosner S, Salmeia KA, Schwarze FW. Using the CODIT model to explain secondary metabolites of xylem in defence systems of temperate trees against decay fungi. Annals of Botany. 2020;125:701720.

11. Eaton RA, Hale MDC. Wood: Decay, pests and protection. Chapman and Hall: London, UK; 1993.

12. Janusz G, Pawlik A, Sulej J, ŚwiderskaBurek U, Jarosz-Wilkołazka A, Paszczyński A. Lignin degradation: Microorganisms, enzymes involved, genomes analysis and evolution. Microbiology Reviews. 2017;41(6):941962.

13. Adler E. Lignin chemistry-past, present and future. Wood Science Technology. 1977;11:169-218.

14. Rowell RM, Roger P, Mandla AT. cell wall chemistry. In: Handbook of Wood Chemistry and Wood Composites, Roger, M. R. (Ed.), Boca Raton: CRC Press; 2012. Available:https://www.routledgehandbooks. com/doi/10.1201/b12487-5 (Accessed $22^{\text {nd }}$ June 2020)

15. Novaes E, Kirst M, Chiang V, WinterSederoff $H$, Sederoff A. Lignin and biomass: A negative correlation for wood formation and lignin content in trees. Plant Physiology. 2010;154(2):555-561.

16. Lourenço A, Pereira $H$. Compositional variability of lignin in biomass. In: Lignin Trends and Applications, (Poletto, M. Ed.). IntechOpen Limited, UK; 2017.

Available:https://www.intechopen.com/boo ks/lignin-trends-andapplications/compositional-variability-oflignin-in-biomass (Accessed $22^{\text {nd }}$ June, 2020)

17. Kirker GT, Blodgett AB, Arango RA, Lebow $\mathrm{PK}$, Clausen CA. The role of extractives in naturally durable wood species. International Biodeterioration \& Biodegradation. 2013;82:53-58.

18. Kretschmann D, Winandy J, Clausen C, Wiemann $M$, Bergman $R$, Rowell R, Zerbe $\mathrm{J}$, Beecher J, White R, McKeever D, Howard J. Wood. In: Kirk-Othmer 
Encyclopedia of Chemical Technology, John Wiley \& Sons, Inc (Ed.); 2007.

DOI:10.1002/0471238961.2315150404211 802.a01.pub2

19. Ajuziogu GC, Ojua EO, Aina DO. Comparative paper-making potentials of three species from the Verbenaceae and Lamiaceae family. Asian Journal of Research in Botany. 2019;2:1-5.

20. Ajuziogu GC, Onyeke CC, Ojua EO, Amujiri AN, Ibeawuchi CC. Effect of growth ring width and fibre dimensions on the compressive strength of some members of the moraceae family. Journal of Wood and Fibre Science. 2019;51:416-423.

21. Hietz $P$, Rosner S, Hietz-Seifert U, Wright SJ. Wood traits related to size and life history of trees in a Panamanian rainforest. New Phytologist. 2017;213:170-180.

22. Maciej AZ, Peter JM, Holbrook NM. Hydraulic properties of individual xylem vessels of Fraxinus americana. Journal of Experimental Botany. 2001;52:257-264.

23. Tyree MT, Ewers FW. The hydraulic architecture of trees and other woody plants. New Phytologist. 1991;119:345360.

24. Choong ET, Tesoro FO. Relationship of capillary pressure and water saturation in wood. Wood Science and Technology. 1989;23:139-150.

25. Sperry JS, Hacke UG, Pitterman J. Size and function in conifers tracheids and angiosperm vessels. American Journal of Botany. 2006;93:1490-1500.

26. McDowell N, Pockman WT, Allen CD, Breshear NC, Kolb T, Plaut J, Sperry J, West A, Williams DG, Yepez EA. Mechanism of plant survival and mortality during drought: Why do some plants survive while others succumb to drought? New Phytologist. 2008;178:719-739.

27. Ajuziogu GC, Ojua EO, Nweze AE, Attah FO. Hydraulic conductivity of some perishable wood species in Southeastern Nigeria: A quantitative approach to determine their treatability. Wood Material Science \& Engineering. (In press) Available:https://doi.org/10.1080/17480272 .2020.1760352

(c) 2020 Ajuziogu et al.; This is an Open Access article distributed under the terms of the Creative Commons Attribution License (http://creativecommons.org/licenses/by/4.0), which permits unrestricted use, distribution, and reproduction in any medium, provided the original work is properly cited.

Peer-review history:

The peer review history for this paper can be accessed here: http://www.sdiarticle4.com/review-history/57817 